\title{
Synthesis and characterization of mononuclear copper(II) complexes of pyridine 2-carboxamide: Their application as catalyst in peroxidative oxidation and antimicrobial agents
}

\author{
SUVENDU SAMANTA $^{\mathrm{a}, * \mathbb{D}, \text { SHOUNAK RAY }^{\mathrm{a}}, \text { SUTAPA JOARDAR }^{\mathrm{b}, *} \text { and SUPRIYA DUTTA }}{ }^{\mathrm{c}}$ \\ ${ }^{a}$ Department of Chemistry, Indian Institute of Engineering Science and Technology, Shibpur, \\ Howrah 711 103, India \\ ${ }^{\mathrm{b}}$ Department of Biotechnology, Neotia Institute of Technology, Management and Science, Jhinga, \\ Diamond Harbour Road, Amira, South 24 Parganas 743 368, India \\ ${ }^{\mathrm{c}}$ Department of Chemistry, Nistarini College, Deshbandhu Road, Purulia, West Bengal 723 101, India \\ e-mail: samanta.suvendu88@gmail.com; sutapajor@yahoo.co.in
}

MS received 20 March 2015; revised 25 May 2015; accepted 30 May 2015

\begin{abstract}
Four water soluble copper(II) complexes, $\left[\mathrm{Cu}(\mathrm{HL})_{2}\left(\mathrm{H}_{2} \mathrm{O}\right)_{2}\right] \mathrm{Cl}_{2}(\mathbf{1}),\left[\mathrm{Cu}(\mathrm{HL})_{2}(\mathrm{ClO})_{2}\right](\mathbf{2})$, $\left[\mathrm{Cu}(\mathrm{HL})_{2}(\mathrm{SCN})_{2}\right](3)$ and $\left[\mathrm{CuL}_{2}\right] \cdot 8 \mathrm{H}_{2} \mathrm{O}(4)$, where $\mathrm{HL}$ is pyridine 2-carboxamide, have been synthesized and characterized by various spectroscopic techniques. Structures have been determined by single crystal X-ray crystallography. The $\mathrm{pH}$ induced inter-conversion of $\left.\mathrm{Cu}(\mathrm{HL})_{2}\left(\mathrm{H}_{2} \mathrm{O}\right)_{2}\right] \mathrm{Cl}_{2}(\mathbf{1})$ and $\left[\mathrm{CuL}_{2}\right] \cdot 8 \mathrm{H}_{2} \mathrm{O}(\mathbf{4})$ through co-ordination mode switching was investigated thoroughly with the help of absorption spectroscopy. Complexes 1-3 were found to be active catalysts for the oxidation of toluene, ethyl benzene and cyclohexane in the presence of hydrogen peroxide as the oxidant under mild conditions. Toluene was oxidized to benzyl alcohol and benzaldehyde, ethyl benzene was oxidized to 1-phenylethanol and acetophenone and cyclohexane was oxidized to yield cyclohexanol and cyclohexanone Antimicrobial activities have been investigated with these copper(II) complexes against gram + ve bacteria, gram - ve bacterial and fungal species.
\end{abstract}

Keywords. Homogeneous catalysis; Copper; Amide ligand; Oxidation; Antimicrobial activity.

\section{Introduction}

Oxidation reactions play a significant role in organic synthesis and presently there is a demand for more selective and efficient oxidation methods. ${ }^{1}$ In recent times, much emphasis has been given to the need for sustainable and environmentally friendly processes. So, the use of oxidants such as molecular oxygen and hydrogen peroxide which are environmentally friendly and produce no toxic waste is highly desirable. The use of molecular oxygen and hydrogen peroxide as the primary oxidant has several benefits such as low cost, improved safety, "green" and water as the sole byproduct. ${ }^{2}$

The oxidation of organic compounds catalyzed by copper(II) complexes under mild condition has also drawn significant attention over the last few decades. ${ }^{3}$ Relatively high abundance of copper in the Earth's crust and its redox properties make it ideally suited for catalytic oxidation processes. In natural enzymes, several copper containing enzymes are known with mono-, di-, tri- or polynuclear $\mathrm{Cu}$ centers that catalyze mild and highly selective oxidative transformations. ${ }^{4}$ These

\footnotetext{
*For correspondence
}

reactions include the poorly characterized particulate methane monooxygenase (pMMO) which is composed of tri- or multinuclear clusters of copper that catalyze conversion of alkanes and alkenes. ${ }^{1 \mathrm{f}-\mathrm{h}}$ Several copper(II) complexes have been exploited as catalyst in various liquid-phase oxidation reactions, ${ }^{5}$ e.g., catechol oxidation, ${ }^{6}$ alkane oxidation (especially cycloalkane),${ }^{7}$ oxidation of aromatic hydrocarbons, ${ }^{7 \mathrm{i}, 8}$ sulfoxidation, ${ }^{9}$ epoxidation,,$^{10}$ etc.

The antibacterial properties of copper(II) have also been known for thousands of years. ${ }^{11}$ Copper(II) complexes with diverse drugs have been the subject of a large number of research studies, ${ }^{12}$ apparently due to the biological role of copper(II) and its synergetic activity with the drug. ${ }^{13}$ The antifungal and antibacterial properties of a range of copper(II) complexes have been evaluated against several pathogenic fungi and bacteria. ${ }^{14} \mathrm{In}$ the literature, it has also been reported that organic ligands exhibit enhanced antibacterial activity once coordinated to copper. ${ }^{14 \mathrm{~b}}$

The carboxamide group, $[-\mathrm{C}(\mathrm{O}) \mathrm{NH}-]$, ubiquitous throughout nature in the primary structure of proteins, is versatile and important ligand construction unit for synthetic coordination chemists. ${ }^{15}$ It is noteworthy to 
mention that neutral amides predominately coordinate to metal ion via the lone pair on the carbonyl oxygen atoms whereas deprotonated amides preferably coordinate to metal ions via their amido nitrogen atom. ${ }^{16}$ The presence of deprotonated carboxamido- $N$ coordination in some metalloenzymes has also motivated the synthetic chemists to design ligand systems with the amide functional group. ${ }^{17} \mathrm{~A}$ wide variety of pyridine 2carboxamide ligands have been synthesized for investigating their coordination properties with metal. ${ }^{18-23}$ Structural investigation of some copper(II) complexes of the simplest pyridine 2-carboxamide ligand (HL) have been reported previously. ${ }^{24}$ But systematic studies of their spectroscopic and electrochemical behaviours are lacking. In the present work, we report X-ray structural characterization, $\mathrm{pH}$ induced co-ordination mode switching phenomenon, peroxidative oxidation catalysis, antimicrobial activity of water soluble discrete mononuclear complexes of copper(II) using the simplest pyridine 2-carboxamide ligand (HL) and its deprotonated form.<smiles>NC(=O)c1ccccn1</smiles>

HL

\section{Experimental}

\subsection{Materials}

All reagents and solvents were purchased from commercial sources and were used as received. The solvents were purified and dried according to standard methods. ${ }^{25}$ Ligand pyridine 2-carboxamide (HL) was synthesized according to the method reported earlier. ${ }^{26}$

\subsection{Synthesis of the metal complexes}

2.2a $\left[\mathrm{Cu}(\mathrm{HL})_{2}\left(\mathrm{H}_{2} \mathrm{O}\right)_{2}\right] \mathrm{Cl}_{2}(\mathbf{l}): 10 \mathrm{~mL}$ solution of $\mathrm{CuCl}_{2}$. $6 \mathrm{H}_{2} \mathrm{O}$ (1 mmol, $\left.0.24 \mathrm{~g}\right)$ in methanol was added dropwise to a methanolic solution $(25 \mathrm{~mL})$ of pyridine 2-carboxamide (HL, $2 \mathrm{mmol}, 0.23 \mathrm{~g}$ ) with stirring at room temperature. The stirring was continued for $1 \mathrm{~h}$, during which time a light blue compound was separated out. The product was filtered off and recrystallized from methanol. Yield $0.35 \mathrm{~g}(85 \%)$. Anal. Calcd. for $\mathrm{C}_{12} \mathrm{H}_{16} \mathrm{CuCl}_{2} \mathrm{~N}_{4} \mathrm{O}_{4}$ : C, 34.92; H, 3.99; N, 13.36. Found: C, 34.75; H, 3.89; $\mathrm{N}, 13.51$. FT-IR (KBr, v/cm ${ }^{-1}$ ) 3448(s), 3269(s, br), 3078(s, br), 1666(s), 1568(s), 1438(s), 1309(w), 1278(w), 1126(m), 1033(m), 783(m), 761(m), 657(m), 503(m). UV-Vis (in $\mathrm{MeOH})\left[\lambda_{\max }, \mathrm{nm}\left(\varepsilon / \mathrm{M}^{-1} \mathrm{~cm}^{-1}\right)\right]: 756(86)$.

2.2b $\left[\mathrm{Cu}(\mathrm{HL})_{2}\left(\mathrm{ClO}_{4}\right)_{2}\right](2)$ : Ligand HL (2 mmol, $\left.0.23 \mathrm{~g}\right)$ was dissolved in $25 \mathrm{~mL}$ of methanol and a $10 \mathrm{~mL}$ solution of $\mathrm{Cu}(\mathrm{ClO} 4)_{2} \cdot 6 \mathrm{H}_{2} \mathrm{O}(1 \mathrm{mmol}, 0.37 \mathrm{~g})$ in methanol was added to it. Solution was stirred for $1 \mathrm{~h}$ during which time a deep blue compound appeared. This was filtered and recrystallized from acetonitrile. Yield $0.35 \mathrm{~g}$ (80\%). Found. C, 28.56; H, 2.51; N, 11.23. Calcd. For $\mathrm{C}_{12} \mathrm{H}_{12} \mathrm{Cl}_{2} \mathrm{CuN}_{4} \mathrm{O}_{10}$ : C, 28.45; H, 2.39; N, 11.06. FTIR $\left(\mathrm{KBr}, v / \mathrm{cm}^{-1}\right)$ 3215(w, br), 3026(s, br), 1666(s), 1560(s), 1438(m), 1037(w), 1145(s), 1110(s), 1087(s), 786(m), 676(m), 661(m), 630(m). UV-Vis (in $\mathrm{MeOH}$ ) $\left[\lambda_{\max }, \mathrm{nm}\left(\varepsilon / \mathrm{M}^{-1} \mathrm{~cm}^{-1}\right)\right]: 748(115)$.

2.2c $\left[\mathrm{Cu}(\mathrm{HL})_{2}(\mathrm{SCN})_{2}\right](3): 5 \mathrm{~mL}$ methanolic solution of $\mathrm{CuCl}_{2} \cdot 6 \mathrm{H}_{2} \mathrm{O}(0.24 \mathrm{~g}, 1 \mathrm{mmol})$ was added to a solution of ligand HL ( $2 \mathrm{mmol}, 0.23 \mathrm{~g}$ ) in $20 \mathrm{~mL}$ methanol. $10 \mathrm{~mL}$ aqueous solution of $\mathrm{NH}_{4} \mathrm{SCN}(2.1 \mathrm{mmol}, 0.16 \mathrm{~g})$ was then added to the resulting faint blue mixture and solution turned to deep green. Solution was stirred for another $20 \mathrm{~min}$ at room temperature. The deep green product was filtered, dissolved in methanol and allowed to stand at room temperature for slow evaporation. Green crystals were obtained after three days. Yield: $0.32 \mathrm{~g}$, (74\%). Found. C, 39.52; H, 2.81; N, 19.90. Calcd. For $\mathrm{C}_{14} \mathrm{H}_{12}$ $\mathrm{CuN}_{6} \mathrm{O}_{2} \mathrm{~S}_{2}$ : C, 39.66; H, 2.85; N, 19.82. FT-IR (KBr, $v / \mathrm{cm}^{-1}$ ) 3269(w, br), 3056(m, br), 2048(s), 1670(s), 1568(m), 1494(w), 1436(s), 1305(m), 1276(w), 1137(m), 1107(w) 1031(m), 952(w), 817(w), 792(w), 754(m), 732(m), 678(m), 663(m). UV-Vis (in $\mathrm{MeOH})\left[\lambda_{\max }, \mathrm{nm}\right.$ $\left.\left(\varepsilon / \mathrm{M}^{-1} \mathrm{~cm}^{-1}\right)\right]: 672(60)$.

2.2d $\left[\mathrm{CuL}_{2}\right] \cdot 8 \mathrm{H}_{2} \mathrm{O}(4): 1 \mathrm{~mL}$ of aqueous solution of sodium hydroxide ( $2 \mathrm{mmol}, 0.08 \mathrm{~g}$ ) was added slowly to aqueous solution of complex 1 ( $1 \mathrm{mmol}, 0.40 \mathrm{~g})$ and stirred for about $5 \mathrm{~min}$. Violet colored crystalline compound that appeared was filtered off and washed with cold ethanol and diethyl ether. Yield 0.35g (85\%). Anal. Calcd. for $\mathrm{C}_{12} \mathrm{H}_{26} \mathrm{CuN}_{4} \mathrm{O}_{10}$ : C, 32.12; H, 5.80; N, 12.55. Found: C, 32.04; H, 5.83; N, 12.45. FT-IR $\left(\mathrm{KBr}, v / \mathrm{cm}^{-1}\right)$ 3431(s, br), 3307 (w), 3240(w), 1631(s), 1597(s), 1566(m), 1440(s), 1271(m), 1047(w), 1022(w), 786(m), 649(w), 607(w), 567(w). UV-Vis (in MeOH) [ $\left.\lambda_{\max }, \mathrm{nm}\left(\varepsilon / \mathrm{M}^{-1} \mathrm{~cm}^{-1}\right)\right]: 570(80)$.

\subsection{Catalytic activity studies}

2-12 mmol of hydrogen peroxide $\left(30 \%\right.$ in $\left.\mathrm{H}_{2} \mathrm{O}\right)$ was added to the catalyst $(0.02 \mathrm{mmol})$ in $5 \mathrm{~mL}$ of acetonitrile 
in a two-neck round bottom flask fitted with a condenser. To this, $\mathrm{HNO}_{3}(0.2 \mathrm{mmol})$ was added followed by the addition of $1.0 \mathrm{mmol}$ of substrate (toluene, ethyl benzene or cyclohexane). The reaction mixture was stirred for $6-14 \mathrm{~h}$ at $60^{\circ} \mathrm{C}$ under atmospheric pressure. After the reaction was over $90 \mu \mathrm{L}$ of chlorobenzene was added as an internal standard and the substrate and products from the reaction mixture were extracted with $10 \mathrm{~mL}$ diethyl ether and then triphenylphosphine $\left(\mathrm{PPh}_{3}\right)$ $(1.0 \mathrm{~g})$ was added to reduce the organo-hydroperoxides. The resultant mixture was stirred for $15 \mathrm{~min}$ and then the sample taken from the organic phase was analyzed by gas chromatography. The identification was done by the comparison with known standards. Blank experiments for the oxidation of substrates were carried out without any catalyst keeping other experimental conditions unaltered.

\subsection{Antimicrobial activity}

The antimicrobial activities of all the synthesized copper(II) complexes were investigated against bacterial strains Gram-positive Bacillus subtilis (MTCC 441), Staphylococcus aureus (MTCC 96), Gram-negative Escherichia coli (MTCC 2939), Pseudomonas aeruginosa (MTCC 2453), Klebsiella pneumonia (MTCC 618) and yeast Saccharomyces cerevisiae (MTCC 170), Candida albicans (MTCC 227) following reported method. ${ }^{27}$ The stock solutions $\left(1 \mathrm{mg} \mathrm{mL}{ }^{-1}\right)$ of the complexes were prepared by dissolving $10 \mathrm{mg}$ of the test compound in $10 \mathrm{~mL}$ of water. The stock solution was suitably diluted with sterilized distilled water to get dilution in between $400-3 \mu \mathrm{g} \mathrm{mL}^{-1}$.

The bacteria were sub-cultured in Müller-Hinton agar. The Petri dishes were incubated for $24 \mathrm{~h}$ at $37^{\circ} \mathrm{C}$. The fungi were sub-cultured in potato dextrose agar medium. The Petri dishes were incubated for $48 \mathrm{~h}$ at $37^{\circ} \mathrm{C}$. Activity was determined by measuring the diameter of the zone $(\mathrm{mm})$ showing complete inhibition of microbial growth that a clear zone surrounding the test sample (in sterile disc) where bacterial growth does not occur (or is inhibited). The growth of the bacteria and fungi were measured by observing the minimum inhibitory concentration.

\subsection{Physical measurements}

Elemental $(\mathrm{C}, \mathrm{H}$ and $\mathrm{N}$ ) analyses were performed on a Perkin-Elmer 2400 II elemental analyzer. IR spectra were recorded using $\mathrm{KBr}$ disks on a Shimadzu FTIR $8400 \mathrm{~S}$ spectrometer. The electronic spectra were recorded at room temperature using an Agilent 8453 diode array spectrophotometer. Gas chromatographic analyses were conducted using an Agilent Technologies 6890 $\mathrm{N}$ network GC system equipped with a fused silica capillary HP-5 column $(30 \mathrm{~m} \times 0.32 \mathrm{~mm})$ and a FID detector. X-band EPR measurements were carried out using a JEOL JES-FA 200 instrument. ${ }^{1} \mathrm{H}$ NMR spectra were obtained using a Bruker Avance DPX $300 \mathrm{MHz}$ spectrometer. Electrochemical measurements were carried out in $\mathrm{N}, \mathrm{N}$-dimethylformamide (DMF) at $25^{\circ} \mathrm{C}$ under nitrogen atmosphere using a Bioanalytical Systems BAS 100B electrochemical analyzer. The concentration of the supporting electrolyte, tetramethylammonium perchlorate (TEAP), was $0.1 \mathrm{M}$, while that of the complex was $1 \mathrm{mM}$. Cyclic voltammetric (CV) and square wave voltammetric (SWV) measurements were carried out using a three-electrode assembly comprising a glassy carbon or platinum working electrode, a platinum auxiliary electrode, and an aqueous $\mathrm{Ag} / \mathrm{AgCl}$ reference electrode. Under the given experimental conditions, the potential of the external standard ferrocene/ferrocenium $\left(\mathrm{Fc} / \mathrm{Fc}^{+}\right)$couple was measured at $+0.390 \mathrm{~V}$ vs. $\mathrm{Ag} / \mathrm{AgCl}$.

\subsection{X-ray crystallography}

Crystals suitable for structure determinations of $\mathbf{1 , 2}, \mathbf{3}$ and $\mathbf{4}$ were obtained by slow evaporation of their watermethanol solutions. The crystals were mounted on glass fibers using perfluoropolyether oil. Intensity data were collected on a Bruker-AXS SMART APEX diffractometer at $123(2) \mathrm{K}$ using graphite-monochromated Mo-K $\alpha$ radiation $(\lambda=0.71073 \AA)$. The data were processed with SAINT $^{28}$ and absorption corrections were made with SADABS software. ${ }^{28}$ The structures were solved by direct and Fourier methods and refined by full-matrix least-squares methods based on $F^{2}$ using SHELX-97.29 For the structure solutions and refinements the SHELX-TL software package ${ }^{30}$ was used. The non-hydrogen atoms were refined anisotropically, while the hydrogen atoms were placed at geometrically calculated positions with fixed thermal parameters. Crystal data and details of structure determination for complex $\mathbf{4}$ are summarized in table 1.

\section{Results and Discussion}

\subsection{Synthesis and characterization}

The synthesis of ligand pyridine 2-carboximidine was carried out following the method reported earlier. ${ }^{26}$ The mononuclear copper(II) complexes, $\left[\mathrm{Cu}(\mathrm{HL})_{2}\left(\mathrm{H}_{2} \mathrm{O}\right)_{2}\right] \mathrm{Cl}_{2}$ (1) and $\left[\mathrm{Cu}(\mathrm{HL})_{2}\left(\mathrm{ClO}_{4}\right)_{2}\right]$ (2) are obtained by the reacting methanolic solution of ligand with $\mathrm{CuCl}_{2} \cdot 6 \mathrm{H}_{2} \mathrm{O}$ or 
Table 1. Crystallographic data for $\left[\mathrm{Cu}(\mathrm{L})_{2}\right] \cdot 8 \mathrm{H}_{2} \mathrm{O}(4)^{a}$.

4

\begin{tabular}{lc}
\hline Empirical formula & $\mathrm{C}_{12} \mathrm{H}_{18} \mathrm{~N}_{4} \mathrm{O}_{6} \mathrm{Cu}$ \\
$M$ & 377.84 \\
$T, \mathrm{~K}$ & $298(2)$ \\
Crystal system & Triclinic \\
Space group & $P-1$ \\
$a / \AA$ & $10.6100(8)$ \\
$b / \AA$ & $11.1360(9)$ \\
$c / \AA$ & $14.7224(11)$ \\
$\alpha /{ }^{\circ}$ & $68.237(2)$ \\
$\beta /{ }^{\circ}$ & $73.419(2)$ \\
$\gamma /{ }^{\circ}$ & $83.203(2)$ \\
$U / \AA^{3}$ & $1548.2(2)$ \\
$Z$ & 4 \\
$D / \mathrm{g} \mathrm{cm}^{-3}$ & 1.621 \\
$\mu / \mathrm{mm}^{-1}$ & 1.448 \\
$F(000)$ & 780.0 \\
Crystal size/mm & $0.38 \times 0.22 \times 0.18$ \\
No. of measured reflections & 21791 \\
No. of observed reflections & 6941 \\
Parmeter refined & 486 \\
No. of reflections $[I>2 \sigma(I)]$ & 4963 \\
Goodness of fit, $S^{[\mathrm{a}]}$ & 1.005 \\
Final $R_{1}^{[b]}, w R_{2}^{[c]}[I>2 \sigma(I)]$ & $0.0373,0.0917$ \\
$R_{1}^{[b]}, w R_{2}^{[c]}$ (all data) & $0.0607,0.1027$ \\
\hline
\end{tabular}

${ }^{a} S=\left[\sum w\left(F \mathrm{o}^{2}-F \mathrm{c}^{2}\right) /(N-P)\right]^{1 / 2}$ where $\mathrm{N}$ is the number of data and $\mathrm{P}$ the total number of parameters refined. [b] $R_{1}(F)=\Sigma\left\|F_{\mathrm{o}}|-| F_{\mathrm{c}}\right\| \Sigma\left|F_{\mathrm{o}}\right| .[\mathrm{c}] w R 2\left(F^{2}\right)=\left[\Sigma \mathrm{w}\left({F_{\mathrm{o}}}^{2}-\right.\right.$ $\left.\left.F_{\mathrm{c}}{ }^{2}\right)^{2} / \Sigma \mathrm{w}\left(F_{\mathrm{o}}{ }^{2}\right)^{2}\right]^{1 / 2}$.

$\mathrm{Cu}\left(\mathrm{ClO}_{4}\right)_{3} \cdot 6 \mathrm{H}_{2} \mathrm{O}$, respectively, while the complex $\left[\mathrm{Cu}(\mathrm{HL})_{2}(\mathrm{SCN})_{2}\right](3)$ is prepared by the direct reaction between the ligand $\mathrm{HL}, \mathrm{CuCl}_{2} \cdot 6 \mathrm{H}_{2} \mathrm{O}$ and $\mathrm{NaSCN}$ in a 1:2:1 ratio in methanol medium. Both compounds $\mathbf{1}$ and 2 upon treatment with 2 equiv of aqueous alkali, undergo deprotonation to produce the compound $\left[\mathrm{CuL}_{2}\right] \cdot 8 \mathrm{H}_{2} \mathrm{O}(\mathbf{4})$.

The IR spectra of the complexes exhibit several diagnostic features. A weak band observed between 3080 and $3025 \mathrm{~cm}^{-1}$ in $\mathbf{1 - 3}$ is due to the hydrogen bonded N-H stretching vibration of the amide $-\mathrm{NH}_{2}$ group. The free ligand has characteristic IR band at $1680 \mathrm{~cm}^{-1}$ due to amide I $[(\mathrm{C}=\mathrm{O})]$ vibration. The metal-coordinated $\mathrm{C}=\mathrm{O}$ vibration in the compounds 1-3 are observed in between $1670-1665 \mathrm{~cm}^{-1}$. On the other hand, compound $\mathbf{4}$ exhibits two strong bands at 1631 and $1597 \mathrm{~cm}^{-1}$, due to $\mathrm{C}=\mathrm{O}$ and $\mathrm{C}=\mathrm{N}$ vibrations, respectively. In a deprotonated $\mathrm{N}$-coordinated amide group it is expected that the negative charge would be delocalized along the amide $\mathrm{C}-\mathrm{N}$ and $\mathrm{C}-\mathrm{O}$ bonds, leading to two resonance forms which have different $\mathrm{C}-\mathrm{N}$ and $\mathrm{C}-\mathrm{O}$ bond lengths. These bonds can also be intermediate between double and single bonds. Due to this partial single bond character, $\mathrm{C}=\mathrm{O}$ vibration appears at much lower frequency $\left(1631 \mathrm{~cm}^{-1}\right)$ and a strong peak due to $\mathrm{C}=\mathrm{N}$ is also observed at $1597 \mathrm{~cm}^{-1}$.

The compound 2 shows four characteristic $\mathrm{ClO}_{4}^{-}$ vibrations for coordinated perchlorate at 1145, 1115, 1088 and $627 \mathrm{~cm}^{-1}$. On the other hand, compound 3 exhibits a strong band at $2048 \mathrm{~cm}^{-1}$ with an ill-defined shoulder at lower energy side due to the presence of thiocyanate group.

\subsection{Description of crystal structure}

The X-ray crystal structures of complexes 1-4 have been determined. It should be mentioned that after determination of the structures of the compounds $\mathbf{1 , 2}$ and $\mathbf{3}$, we found that the X-ray structure of these three compounds have been reported earlier. ${ }^{24}$ The structure determination of 2 by us has been made at $120 \mathrm{~K}$ whereas the reported one was made at 293 K. Accordingly, the unit cell parameters found in the present case are relatively shorter as compared to the earlier reported values. ${ }^{24}$ The influence of temperature can be appreciated by comparing the unit cell volume, which is $442.3(2) \AA^{3}$ at $120 \mathrm{~K}$ as against $457.26(15) \AA^{3}$ at $293 \mathrm{~K}$. In terms of $\mathrm{Cu}-\mathrm{N}$ and $\mathrm{Cu}-\mathrm{O}$ (amide) distances, the difference observed in the two sets of studies are insignificant, albeit the $\mathrm{Cu}-\mathrm{O}\left(\mathrm{ClO}_{4}\right)$ distance reported here $[2.612(2) \AA]$ is somewhat shorter compared to the reported value $[2.649(3) \AA]$. The thermal ellipsoid plot of the compounds 1-3 are shown in figures S1-S3 and relevant bond distances and bond angles are given in tables S1-S3. Crystal data and details of structure determinations for complex 1-3 are summarized in table S4. Figure S4-S6 show intermolecular hydrogen bonding network in compounds $\mathbf{1}-\mathbf{3}$.

3.2a $\left[\mathrm{CuL}_{2}\right] \cdot 8 \mathrm{H}_{2} \mathrm{O}(4)$ : In compound 4 , the asymmetric unit contains three independent $\left[\mathrm{CuL}_{2}\right]$ molecules and eight water molecules of crystallization. A thermal ellip soid plot of the structural arrangement of the asymmetric unit is shown in figure 1 and the relevant metrical parameters involving the metal centers are given in table 2 . In all the three units, the coordination environment around the four-coordinated metal centre $\left[\mathrm{CuN}_{4}\right]$ may be considered perfect square planar. The $\mathrm{Cu}-\mathrm{N}$ (pyridine) distances are almost equal lying in all the units between 2.0179 (19) to 2.027 (2) A but somewhat longer relative to the $\mathrm{Cu}-\mathrm{N}$ (amide) distances which are also nearly identical, lying in all the units between 1.924 (2) to 1.932 (2) $\AA$. The cisoid angles vary from $81.26(8)^{\circ}$ to $98.89(8)^{\circ}$, while the transoid angles are $175.24(7)^{\circ}$ and $180.00(2)^{\circ}$. Thus, copper centres have a near perfect square planar geometry. 

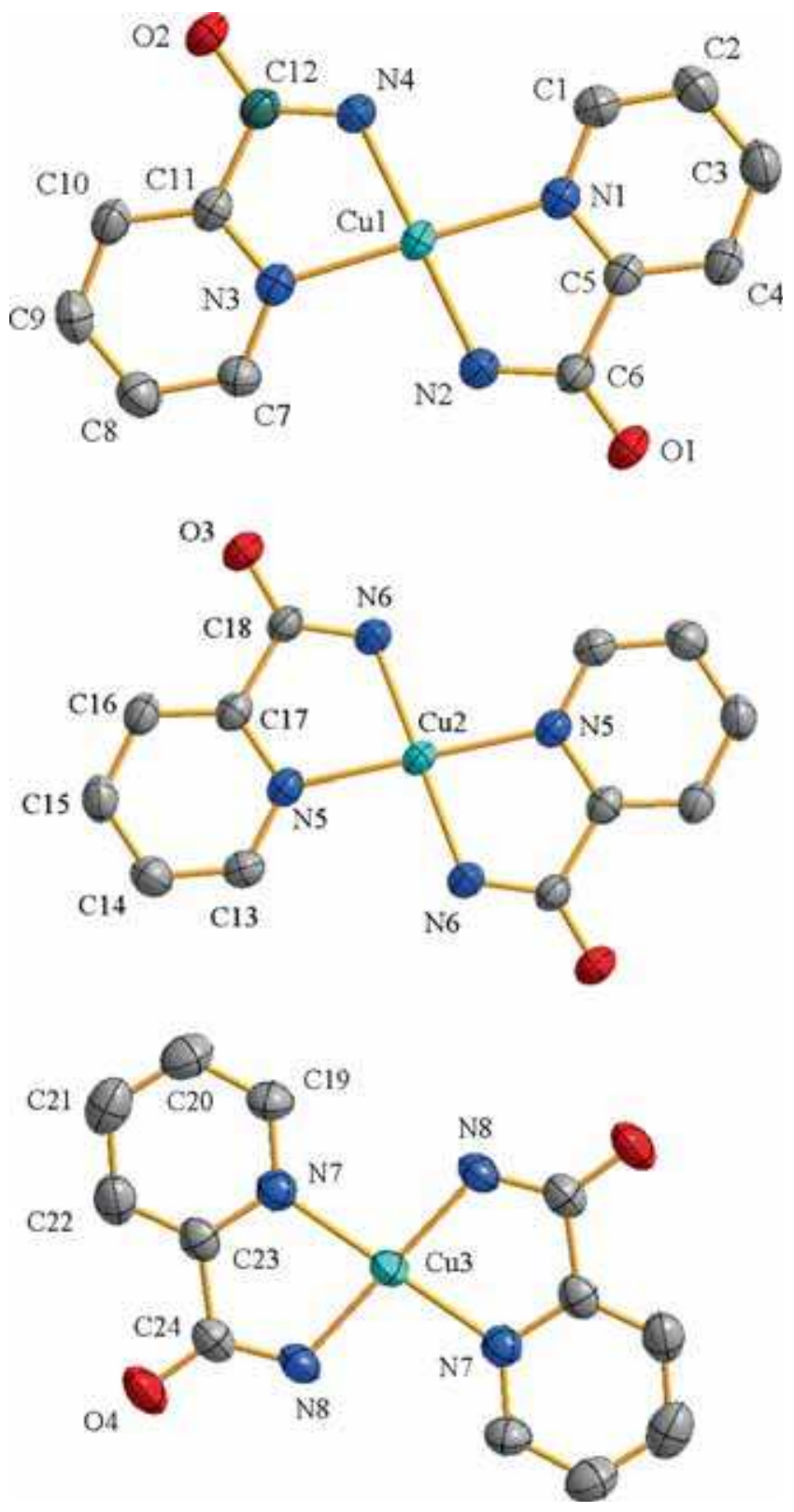

Figure 1. An ORTEP representation of the molecule $\left[\mathrm{Cu}(\mathrm{L})_{2}\right] \cdot 8 \mathrm{H}_{2} \mathrm{O}(4)$ showing $50 \%$ probability displacement ellipsoids. Hydrogen atoms and waters of crystallization are removed for clarity.

Interestingly, this framework hosts chains of hydrogenbonded clusters of molecules of crystallization water (figure $\mathrm{S} 7$ ). Each tetradecameric, $\left(\mathrm{H}_{2} \mathrm{O}\right)_{14}$, cluster is formed by a cyclic water decamer and four pendent water molecules (figure 2a). Among the eight water molecules, five water molecules are generated by an inversion centre to form a cyclic water decamer. The cyclic decamer assumes a boat-chair-boat conformation (figure 2b). In the $\left(\mathrm{H}_{2} \mathrm{O}\right)_{14}$ cluster, the average $\mathrm{O}_{\text {water }} \cdots \mathrm{O}_{\text {water }}$ separation of ca. $2.789 \AA$ (table S5) within the decameric core is almost same as that of ca. $2.829 \AA[\mathrm{O}(7)-$ $\mathrm{H}(7 \mathrm{~B}) \cdots \mathrm{O}(5)$ and $\mathrm{O}(12)-\mathrm{H}(12 \mathrm{~A}) \cdots \mathrm{O}(11)$, table S5] connecting dangling water molecules. Both values are comparable to the average $\mathrm{O}_{\text {water }} \cdots \mathrm{O}_{\text {water }}$ contact of ca. $2.85 \AA$ found in liquid water and in other $\mathrm{H}_{2} \mathrm{O}$ clusters hosted by metal-organic frameworks. ${ }^{31}$ The $\mathrm{O} \cdots \mathrm{O} \cdots \mathrm{O}$ angles range from $84.24^{\circ}$ to $131.02^{\circ}$ (table S5), considerably deviating from the preferred ideal tetrahedral geometry of water. The tetradecameric water clusters are further linked by hydrogen bonds to form infinite parallel two dimensional sheet intercalated in voids of the host metal-organic matrix of $\mathbf{4}$ (figure S7). The four dangling $\mathrm{H}_{2} \mathrm{O}$ molecules of every water cluster also have a structure-stabilizing effect, each of them being hydrogen bonded to oxygen atoms of amide group of a pyridine 2-carboxamide ligand. Thus, $\left(\mathrm{H}_{2} \mathrm{O}\right)_{14}$ cluster forms two-dimensional sheets, and copper complexes act as connectors to those sheets to form three-dimensional packing arrays (figure S7).

The packing diagram of compound $\mathbf{4}$ also reveals the presence of two intermolecular $\pi-\pi$ interaction between the pyridine ring $\mathrm{C} 1, \mathrm{C} 2, \mathrm{C} 3, \mathrm{C} 4, \mathrm{C} 5$, and $\mathrm{N} 1$ with the pyridine ring $\mathrm{C} 13, \mathrm{C} 14, \mathrm{C} 15, \mathrm{C} 16, \mathrm{C} 17$, and N5 [the distance between the two centroids is $3.701 \AA$ ] and second one is between the pyridine ring $\mathrm{C} 13, \mathrm{C} 14$, $\mathrm{C} 15, \mathrm{C} 16, \mathrm{C} 17$, and $\mathrm{N} 5$ with the pyridine ring $\mathrm{C} 7, \mathrm{C} 8$, $\mathrm{C} 9, \mathrm{C} 10, \mathrm{C} 11$, and $\mathrm{N} 3$ [the distance between the two centroids is $3.693 \AA$ ] .

The N, N-coordination mode of pyridine-2-carboxamide is quite rare. ${ }^{24 \mathrm{~d}, \mathrm{e}}$ The structure of $\left[\mathrm{Cu}(\text { pia })_{2}\right]$. $4 \mathrm{H}_{2} \mathrm{O}^{24 \mathrm{~d}}$ and $\left[\mathrm{Cu}(\text { pia })_{2}\right] \cdot 2 \mathrm{H}_{2} \mathrm{O}^{24 \mathrm{e}}$ have been reported previously. The main difference between the previous two complexes with our complex, apart from the number of co-crystallized water molecules, is the presence of three independent $\left[\mathrm{CuL}_{2}\right]$ molecules in an asymmetric unit.

\subsection{Electronic spectra}

The absorption spectroscopic behaviour of compounds 1-4 have been studied in methanol. The Vis-NIR spectral data for these compounds in methanol are given in Experimental Section. The six-coordinated octahedral copper(II) complexes, 1-3 exhibit a broad band in the visible and Near IR range due to $d-d$ transition (675$760 \mathrm{~nm}$ ) though three transition bands are expected for tetragonally elongated octahedral geometry. The broadness of these bands with a low energy tail are indicative of the presence of more than one transitions at lower energies, as expected for copper(II) in a tetragonally elongated octahedral environment. In general, the electronic spectra of octahedrally coordinated copper(II) complexes are dominated by Jahn-Teller-induced tetragonal distortions, which give rise to a characteristic broad band formed due to overlap of the three bands. Indeed, 
Table 2. Selected bond lengths $[\AA]$ and angles $\left[{ }^{\circ}\right]$ for $\left[\mathrm{Cu}(\mathrm{L})_{2}\right] \cdot 8 \mathrm{H}_{2} \mathrm{O}(\mathbf{4})^{a}$.

\begin{tabular}{lccccc}
\hline \multicolumn{7}{c}{4} \\
Cu1-N1 & $2.0179(19)$ & Cu2-N5 & $2.027(2)$ & Cu3-N7 & $2.013(2)$ \\
Cu1-N2 & $1.928(2)$ & Cu2-N6 & $1.929(2)$ & Cu3-N8 & $1.931(2)$ \\
Cu1-N3 & $2.0233(19)$ & Cu2-N5A & $2.027(2)$ & Cu3-N7B & $2.013(2)$ \\
Cu1-N4 & $1.924(2)$ & Cu2-N6A & $1.930(2)$ & Cu3-N8B & $1.932(2)$ \\
& & & & & \\
N1-Cu1-N2 & $81.39(8)$ & N5-Cu2-N6 & $81.49(8)$ & N7-Cu3-N8 & $81.99(9)$ \\
N1-Cu1-N3 & $175.24(7)$ & N5-Cu2-N6A & $98.51(8)$ & N7-Cu3-N8B & $98.01(9)$ \\
N1-Cu1-N4 & $98.89(8)$ & N6-Cu2-N6A & $180.00(12)$ & N7-Cu3-N7B & $180.00(19)$ \\
N2-Cu1-N3 & $98.34(8)$ & N5A-Cu2-N6A & $81.49(8)$ & N7B-Cu3-N8 & $98.01(9)$ \\
N2-Cu1-N4 & $178.45(9)$ & N5-Cu2-N5A & $180.00(9)$ & N8-Cu3-N8B & $180.00(2)$ \\
N3-Cu1-N4 & $81.26(8)$ & N5A-Cu2-N6 & $98.51(8)$ & N7B-Cu3-N8B & $81.99(9)$ \\
\hline
\end{tabular}

[a] 'A' indicates atoms at $(-x,-y, 1-z)$ and ' $B$ ' indicates atoms at $(2-x,-y,-z)$.
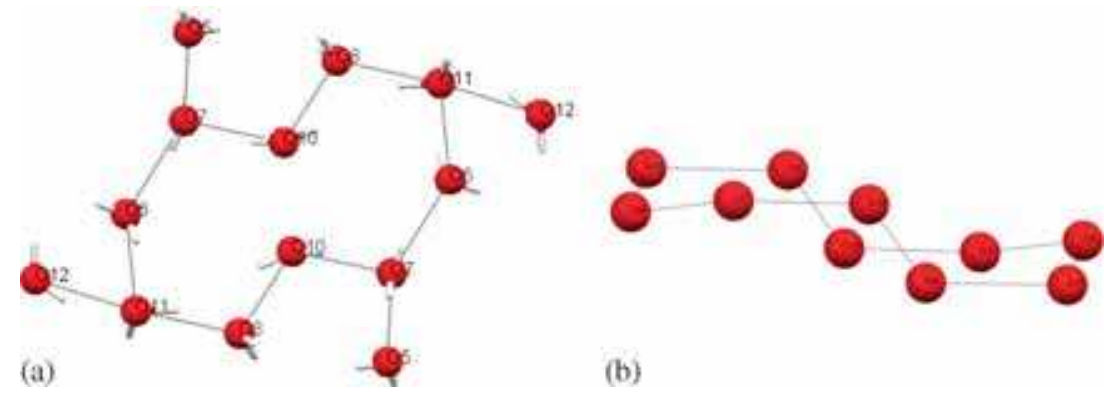

(b)

Figure 2. (a) Perspective representations of the tetradecameric, $\left(\mathrm{H}_{2} \mathrm{O}\right)_{14}$, cluster formed by a cyclic water decamer and four pendent water molecules.

(b) The boat-chair-boat conformation of cyclic water decamer.
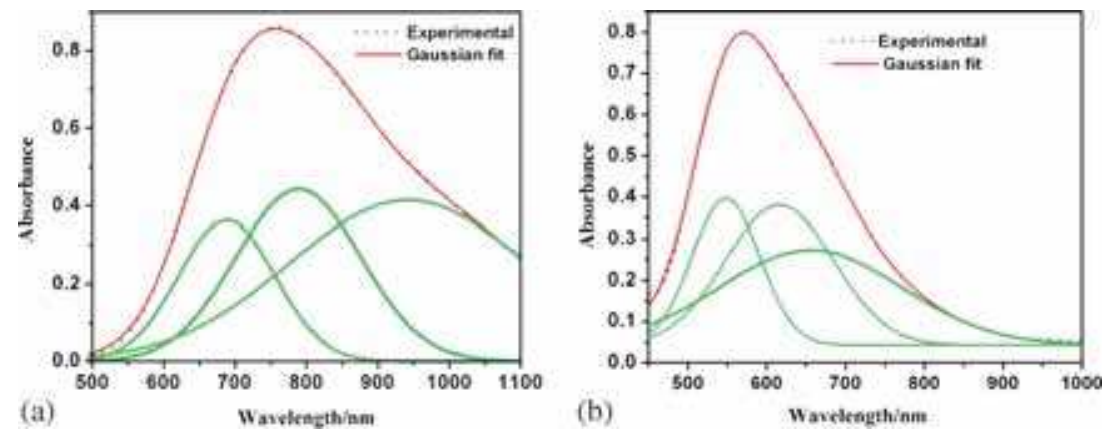

Figure 3. Visible and near infrared absorption spectra of the compounds (a) $\left[\mathrm{Cu}(\mathrm{HL})_{2}\left(\mathrm{H}_{2} \mathrm{O}\right)_{2}\right] \mathrm{Cl}_{2}(\mathbf{1})$ and $(\mathrm{b})\left[\mathrm{Cu}(\mathrm{L})_{2}\right] \cdot 8 \mathrm{H}_{2} \mathrm{O}(\mathbf{4})$ in methanol $\left(1 \times 10^{-2} \mathrm{M}\right)$. The three bands below the spectrum are obtained by Gaussian line-shape analysis and added together give the experimental line.

deconvolution of the absorption spectra of $\mathbf{1 - 3}$ in methanol by Gaussian line-shape analysis gives rise to three peaks. The spectral data and the deconvoluted peak positions of 1-4 in methanol are listed in table S6. Square planar copper(II) complex, 4, also shows one broad band at relatively higher energy $(570 \mathrm{~nm})$ due to $d-d$ transition. Deconvolution of the absorption spectrum of $\mathbf{4}$ in methanol by Gaussian line-shape analysis gives rise to three peaks as expected for square planar $\mathrm{Cu}$ (II) complexes. Figure 3 shows deconvoluted peaks in compounds $\mathbf{1}$ and $\mathbf{4}$.

\subsection{EPR spectra}

X-band EPR spectrum of the complexes 1-4, have been carried out in 4:1 ethanol-methanol solution at $77 \mathrm{~K}$ (figure 4). EPR spectra of complexes 1-3, show axially symmetric copper(II) centres ${ }^{32}$ with $g_{\perp}=2.073, g_{\|}=$ $2.31 ; g_{\perp}=2.045, g_{\|}=2.19 ; g_{\perp}=2.046, g_{\|}=2.34$ for complexes 1, $\mathbf{2}$ and 3, respectively. These values also indicate that the ground state of $\mathrm{Cu}$ (II) is predominantly $d_{\mathrm{x}-\mathrm{y}}^{2}$. Complex 4 exhibits a slight rhombic signal with $g_{\|}(2.24)>g_{\perp}(2.063)$ and $g_{\mathrm{av}}=2.063$. This type of signal 


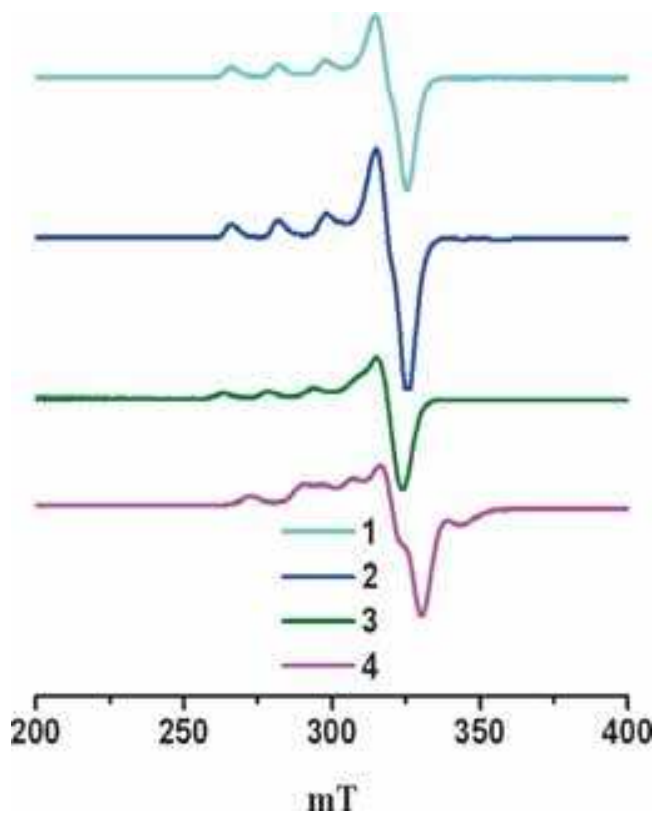

Figure 4. X-band EPR spectra of the complexes 1-4 under nitrogen in a frozen $\mathrm{EtOH}-\mathrm{MeOH}(4: 1)$ solvent mixture at $77 \mathrm{~K}$.

is common for square planar copper(II) complexes with $\left(d_{\mathrm{x}-\mathrm{y}}^{2}{ }^{2}\right)$ magnetic orbital. ${ }^{32}$

\subsection{Electrochemistry}

The electrochemical characteristics of complexes 1-4 in dimethyl formamide have been investigated by cyclic and square wave voltammetric methods. The $E_{1 / 2}$ values obtained by the two methods agree within $\pm 5 \mathrm{mV}$. The conventional accuracy of the $E_{1 / 2}$ values by these techniques, of course, is taken as $\pm 10 \mathrm{mV}$. In case of complexes 1-3, the metal-centered reductions take place quasi-reversibly. The relevant electrochemical data for the complexes 1-4 are given in table S7. In dimethyl formamide, the $E_{1 / 2}$ value of $\left[\mathrm{CuL}_{2}\left(\mathrm{H}_{2} \mathrm{O}\right)_{2}\right] \mathrm{Cl}_{2}$ (1) is $435 \mathrm{mV}$ with $\Delta E_{\mathrm{p}}=130 \mathrm{mV}$ (figure $\mathrm{S} 8 \mathrm{a}$ ), that of $\left[\mathrm{Cu}(\mathrm{HL})_{2}\left(\mathrm{ClO}_{4}\right)_{2}\right](2)$ is $60 \mathrm{mV}$ with $\Delta E_{\mathrm{p}}=115 \mathrm{mV}$ (figure $\mathrm{S} 8 \mathrm{~b}$ ) and finally for the $\left[\mathrm{Cu}(\mathrm{HL})_{2}(\mathrm{SCN})_{2}\right](3)$ the $E_{1 / 2}$ and $\Delta E_{\mathrm{p}}$ values are $390 \mathrm{mV}$ and $135 \mathrm{mV}$ (figure S8c). Square planar complex $\left[\mathrm{CuL}_{2}\right] \cdot 8 \mathrm{H}_{2} \mathrm{O}(4)$ exhibits one irreversible reduction peak (figure S8d) at about $570 \mathrm{mV}\left(E_{\mathrm{p}, \mathrm{c}}\right)$.

\section{6 pH induced co-ordination mode switching}

The possible inter-conversion between $\left[\mathrm{Cu}(\mathrm{HL})_{2}\left(\mathrm{H}_{2}\right.\right.$ $\left.\mathrm{O})_{2}\right] \mathrm{Cl}_{2}(\mathbf{1})$ and $\left[\mathrm{CuL}_{2}\right] \cdot 8 \mathrm{H}_{2} \mathrm{O}(4)$ through co-ordination mode switching was then investigated. In aqueous medium, $\left[\mathrm{Cu}(\mathrm{HL})_{2}\left(\mathrm{H}_{2} \mathrm{O}\right)_{2}\right] \mathrm{Cl}_{2}(\mathbf{1})$ and $\left[\mathrm{CuL}_{2}\right] \cdot 8 \mathrm{H}_{2} \mathrm{O}(\mathbf{4})$ show one broad band at 685 and $575 \mathrm{~nm}$, respectively, due to $d-d$ transition. Upon addition of sodium hydroxide solution to an aqueous solution of compound $\mathbf{1}$, the light blue solution $\left(\lambda_{\max }=685 \mathrm{~nm}\right)$ turned gradually violet $\left(\lambda_{\max }=575 \mathrm{~nm}\right)$ in accordance with the formation of the $\left[\mathrm{CuL}_{2}\right] \cdot 8 \mathrm{H}_{2} \mathrm{O}(4)$ complex (figure 5). No further change in spectrum was observed after addition of two equivalent of alkali. Conversely, upon the addition of hydrochloric acid to a violet solution of $\left[\mathrm{CuL}_{2}\right] \cdot 8 \mathrm{H}_{2} \mathrm{O}$ (4), the initial absorption at $\lambda_{\max }=575 \mathrm{~nm}$ was replaced by a band at $685 \mathrm{~nm}$ characteristic of the compound 1 in aqueous solution.

We have also carried out potentiometric titration to obtain the $\mathrm{p} K_{\mathrm{a}}$ values for the amide hydrogens. The potentiometric titration was carried out over a $\mathrm{pH}$ range of 3.5-10.5. The titration of $\left[\mathrm{Cu}(\mathrm{HL})_{2}\left(\mathrm{H}_{2} \mathrm{O}\right)_{2}\right] \mathrm{Cl}_{2}$ (1) $(10 \mathrm{mM})$ in water at $25^{\circ} \mathrm{C}$ and $I=0.1 \mathrm{M}$ (sodium perchlorate) gave one well-defined inflection. The $\mathrm{pKa}$ value was determined from the titration curve to be 7.15 and the deprotonating number was determined to be two at the inflection point as shown in figure S9.

\subsection{Oxidation of Toluene, Ethyl Benzene and Cyclohexane}

We investigated the catalytic potential of compounds $\mathbf{1}$, $\mathbf{2}$ and $\mathbf{3}$ for the oxidation of various organic substrates such as toluene, ethyl benzene and cyclohexane by aqueous hydrogen peroxide under mild conditions. The reaction occurs in acetonitrile solution, and nitric acid in low concentration is a necessary component of the reaction mixture. It has been reported earlier ${ }^{33}$ that the nitric acid increases the unsaturation at the metal center by protonation of the ligand of the catalyst and hence increases oxidative properties of the catalyst. In

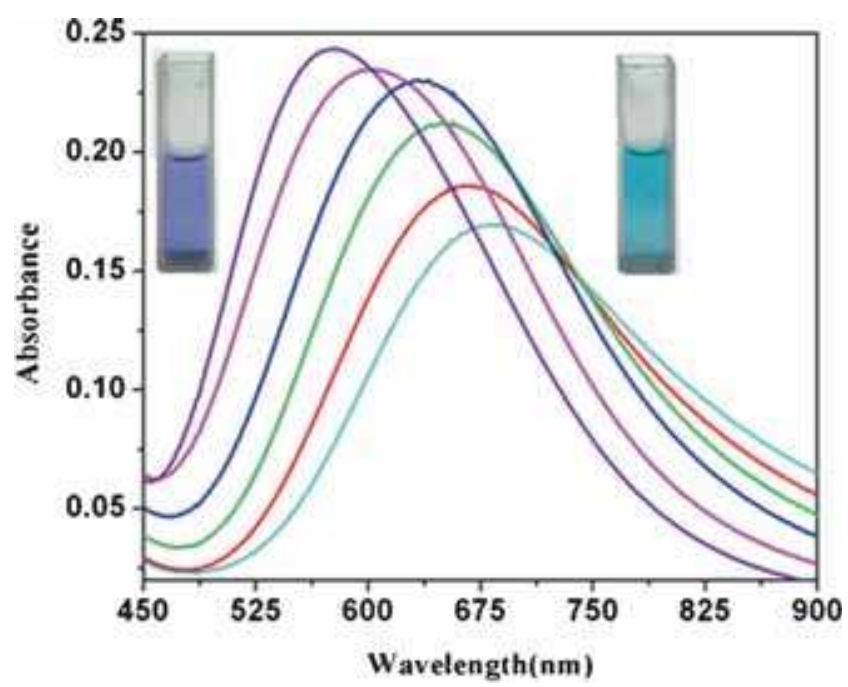

Figure 5. Change in absorption spectra of $\mathbf{1}$ in aqueous solution upon the addition of $\mathrm{OH}^{-}$ion. 
Table 3. Oxidation ${ }^{[\mathrm{a}]}$ of toluene by complexes $\mathbf{1}, \mathbf{2}$ and $\mathbf{3}$.

\begin{tabular}{|c|c|c|c|c|c|c|c|c|}
\hline \multirow[b]{2}{*}{ Entry } & \multirow[b]{2}{*}{ Catalysts } & \multirow[b]{2}{*}{$\begin{array}{l}n\left(\mathrm{H}_{2} \mathrm{O}_{2}\right) / \\
n(\text { catalyst })\end{array}$} & \multirow[b]{2}{*}{ Time/h } & \multicolumn{3}{|c|}{ Yield $(\%)^{[\mathrm{b}]}$} & \multirow[b]{2}{*}{$\begin{array}{l}\text { Benzyl Alcohol } \\
\text { Selectivity }(\%)\end{array}$} & \multirow[b]{2}{*}{$\mathrm{TON}^{[\mathrm{c}]}$} \\
\hline & & & & Benzyl Alcohol & Benzaldehyde & Total & & \\
\hline 1 & 1 & 100 & 10 & 46.4 & 24.1 & 70.5 & 65.8 & 35.25 \\
\hline 2 & & 200 & 10 & 51.2 & 30.8 & 78.4 & 65.3 & 39.20 \\
\hline 3 & & 400 & 10 & 49.1 & 31.9 & 81.0 & 60.6 & 40.50 \\
\hline 4 & & 500 & 10 & 49.9 & 36.4 & 86.3 & 57.8 & 43.15 \\
\hline 5 & & 600 & 10 & 51.0 & 41.4 & 92.4 & 55.2 & 46.20 \\
\hline 6 & & 600 & 8 & 51.4 & 40.6 & 92.0 & 55.9 & 46.00 \\
\hline 7 & & 600 & 6 & 51.1 & 40.9 & 92.0 & 55.6 & 46.00 \\
\hline 8 & 2 & 100 & 12 & 48.1 & 19.9 & 68.0 & 70.7 & 34.00 \\
\hline 9 & & 200 & 12 & 49.5 & 23.0 & 72.5 & 68.3 & 36.25 \\
\hline 10 & & 400 & 12 & 49.8 & 26.1 & 75.9 & 65.6 & 37.95 \\
\hline 11 & & 500 & 12 & 50.3 & 29.8 & 80.1 & 62.8 & 40.05 \\
\hline 12 & & 600 & 12 & 53.1 & 36.6 & 89.7 & 59.2 & 44.85 \\
\hline 13 & & 600 & 10 & 54.5 & 36.4 & 90.9 & 59.9 & 45.45 \\
\hline 14 & & 600 & 8 & 52.9 & 37.3 & 90.2 & 58.6 & 45.10 \\
\hline 15 & 3 & 100 & 14 & 28.2 & 20.0 & 48.2 & 58.4 & 24.10 \\
\hline 16 & & 200 & 14 & 35.4 & 25.9 & 61.3 & 57.7 & 30.65 \\
\hline 17 & & 400 & 14 & 36.8 & 29.9 & 66.7 & 55.2 & 33.35 \\
\hline 18 & & 500 & 14 & 37.7 & 33.3 & 71.0 & 53.1 & 35.50 \\
\hline 19 & & 600 & 14 & 40.6 & 36.2 & 76.8 & 52.9 & 38.40 \\
\hline 22 & & 600 & 12 & 40.0 & 35.2 & 75.2 & 53.2 & 37.60 \\
\hline 21 & & 600 & 11 & 39.9 & 33.8 & 73.7 & 54.1 & 36.85 \\
\hline 22 & $\mathrm{Cu}\left(\mathrm{ClO}_{4}\right)_{2} \cdot 6 \mathrm{H}_{2} \mathrm{O}$ & 600 & 12 & 5.9 & 3.1 & 9.0 & - & 4.50 \\
\hline 23 & $\mathrm{CuCl}_{2} \cdot 6 \mathrm{H}_{2} \mathrm{O}$ & 600 & 12 & 6.1 & 3.3 & 9.4 & - & 4.70 \\
\hline 24 & None & 600 & 12 & 2.7 & 2.1 & 4.8 & - & 2.40 \\
\hline
\end{tabular}

[a] solvent $=\mathrm{CH}_{3} \mathrm{CN}, 333 \mathrm{~K}$, oxidant $=$ hydrogen peroxide. [b] Calculated after treatment with $\mathrm{PPh}_{3}$. [c] TON: turn over number $=$ moles of product $/$ mole of catalyst.

presence of nitric acid, decomposition of peroxide, which is present in the reaction medium, is slowed down and thus, the stability of peroxo intermediate is enhanced. The yield has been optimized by varying the relative proportions of nitric acid and hydrogen peroxide with respect to the catalysts, and also by varying the reaction time. The reaction gives alkyl or aryl hydroperoxides which are gradually transformed into the corresponding ketones (aldehydes) and alcohols. The final concentrations of the ketones (aldehydes) and alcohols were measured after the addition of $\mathrm{PPh}_{3}$ in accord with the method developed earlier by Shuĺpin. ${ }^{34}$ As catalytic reaction was done in presence of acidic medium, compound $\mathbf{4}$ has not been considered as catalyst.

The influence of various parameters such as the relative amounts of nitric acid, hydrogen peroxide, and catalyst on the catalytic activity has been investigated aiming at the optimization of the oxidation process. No oxidation products (or only traces) were obtained in the absence of catalyst or hydrogen peroxide. We have also verified that the presence of nitric acid is important in such oxidation reactions. When the oxidation of the substrate is carried out without nitric acid, it results in much lower yields for all complexes. The amount of oxidized products increased drastically with addition of acid up to 10 equiv, beyond which the yield drops. The relatively low amount of acid required to reach a maximum of activity of $\mathbf{1 - 3}$ is in agreement ${ }^{35}$ with the low-coordination number of copper and the presence of labile $\mathrm{H}_{2} \mathrm{O}, \mathrm{ClO}_{4}^{-}$or $\mathrm{SCN}^{-}$ligands. On the basis of these observations, further catalytic activity tests were run at the $n\left(\mathrm{HNO}_{3}\right) / n$ (catalyst) molar ratio of 10 . Simple copper salts, like $\mathrm{Cu}\left(\mathrm{NO}_{3}\right)_{2} \cdot 6 \mathrm{H}_{2} \mathrm{O}$ or $\mathrm{CuCl}_{2} \cdot 6 \mathrm{H}_{2} \mathrm{O}$, under the same reaction conditions exhibit a much lower activity towards oxidation of all substrates (entries 22, 23 and 24 of table 6), under the same experimental conditions. So it is evident that the presence of $\mathrm{N}$ and $\mathrm{O}$ donor ligands is quite relevant. The oxidation reactions were also carried out at $333 \mathrm{~K}$. On increasing temperature from room temperature to $333 \mathrm{~K}$, yield increases significantly. When the temperature of the oxidation reactions was increased further, no significant improvement in yield was observed. So we have performed all the catalytic reactions at $333 \mathrm{~K}$. 
The results of the oxidation of toluene, ethyl benzene and cyclohexane are shown in tables 3, 4 and 5, respectively. It can be clearly seen from table 3 that among all the catalysts, complex $\mathbf{1}$ is the most efficient catalyst for the oxidation of toluene with $92.0 \%$ (entry 7 , table 3 ) conversion of toluene when the $n\left(\mathrm{H}_{2} \mathrm{O}_{2}\right) / n$ (catalyst) ratio is 600 , with a reaction time of $6 \mathrm{~h}$. The maximum conversions of toluene achieved are $90.2 \%$ (entry 14, table 3 ) and $73.7 \%$ (entry 21, table 3 ) with complexes 2 and $\mathbf{3}$, respectively, in the presence of different amounts of hydrogen peroxide and with somewhat longer reaction time. It has been observed for all the catalytic conversions that the yield increases with time. Catalytic conversions are also dependent on the amount of oxidant used. The results of the oxidation of toluene show good conversion rate as well as TON and TOF (table 3, entries 7, 14 and 21).

Among three catalysts, complexes $\mathbf{1}$ and $\mathbf{2}$ are almost equally efficient catalyst for the oxidation of ethyl benzene with $74.0 \%$ (entry 7, table 4) and $72.2 \%$ (entry 14 , table 4) conversion of ethyl benzene when the $n\left(\mathrm{H}_{2} \mathrm{O}_{2}\right)$ / $n$ (catalyst) ratio is 600 , with a reaction time of $8 \mathrm{~h}$. The maximum conversion of ethyl benzene achieved is $57.6 \%$ (entry 21 , table 4 ) with complex $\mathbf{3}$, in the presence of different amounts of hydrogen peroxide.
The results of cyclohexane oxidation are shown in table 5. It is clearly seen that the conversion of cyclohex ane is influenced by the relative amounts of hydrogen peroxide and the reaction period. The corresponding products are cyclohexanol and cyclohexanone in the case of cyclohexane oxidation. Among three catalysts, again complexes $\mathbf{1}$ and $\mathbf{2}$ are almost equally efficient catalyst for the oxidation of cyclohexane with $862 \%$ (entry 6, table 5) and $841 \%$ (entry 12 , table 5) conversion of cyclohexane when the $n\left(\mathrm{H}_{2} \mathrm{O}_{2}\right) / n$ (catalyst) ratio is 500, with a reaction time of $6 \mathrm{~h}$. The maximum conversion of cyclohexane achieved is $73.0 \%$ (entry 18 , table 5) with complex $\mathbf{3}$, in the presence of different amounts of hydrogen peroxide.

The proposed mechanism of the catalytic conversion is schematically given in scheme S1. Metal-assisted decomposition of $\mathrm{H}_{2} \mathrm{O}_{2}$ could lead to the formation of hydroxyl radical ( $\mathrm{HO}^{\prime}$ ) which, upon $\mathrm{H}$-abstraction from $\mathrm{RH}$, would form the alkyl radical ( $\mathrm{R} \cdot$ ). The formation of the $\mathrm{HO}$ radical involves proton-transfer steps among $\mathrm{H}_{2} \mathrm{O}_{2}$, hydroperoxo and peroxo metal-species, as suggested earlier, ${ }^{35 \mathrm{~b}, \mathrm{f}}$ which can be promoted by the N,O-donor pyridine 2-carboxamide ligand. The alkyl radical, on reaction with a metal-peroxo intermediate species $\mathrm{LCu}-\mathrm{OOH}$, could form $\mathrm{ROOH}$ which, upon

Table 4. Oxidation ${ }^{[\mathrm{a}]}$ of ethyl benzene by complexes 1, 2 and $\mathbf{3}$.

\begin{tabular}{|c|c|c|c|c|c|c|c|c|}
\hline \multirow[b]{2}{*}{ Entry } & \multirow[b]{2}{*}{ Catalysts } & \multirow[b]{2}{*}{$\begin{array}{l}n\left(\mathrm{H}_{2} \mathrm{O}_{2}\right) / \\
n(\text { catalyst })\end{array}$} & \multirow[b]{2}{*}{ Time/h } & \multicolumn{3}{|c|}{ Yield $(\%)^{[\mathrm{b}]}$} & \multirow[b]{2}{*}{$\begin{array}{l}\text { 1-phenylethanol } \\
\text { Selectivity }(\%)\end{array}$} & \multirow[b]{2}{*}{$\mathrm{TON}^{[\mathrm{c}]}$} \\
\hline & & & & 1-phenylethanol & Acetophenone & Total & & \\
\hline 1 & 1 & 100 & 10 & 36.7 & 17.4 & 54.1 & 67.8 & 27.05 \\
\hline 2 & & 200 & 10 & 39.1 & 19.9 & 59.0 & 66.3 & 29.50 \\
\hline 3 & & 400 & 10 & 40.1 & 24.0 & 64.1 & 62.6 & 32.05 \\
\hline 4 & & 500 & 10 & 41.4 & 29.0 & 70.4 & 58.8 & 35.20 \\
\hline 5 & & 600 & 10 & 41.9 & 34.0 & 75.9 & 55.2 & 37.95 \\
\hline 6 & & 600 & 9 & 41.2 & 33.8 & 75.0 & 54.9 & 37.50 \\
\hline 7 & & 600 & 8 & 41.2 & 32.8 & 74.0 & 55.7 & 37.00 \\
\hline 8 & 2 & 100 & 10 & 33.7 & 12.7 & 46.4 & 72.7 & 23.20 \\
\hline 9 & & 200 & 10 & 36.2 & 15.4 & 51.6 & 70.1 & 25.80 \\
\hline 10 & & 400 & 10 & 39.9 & 17.5 & 57.4 & 69.5 & 28.70 \\
\hline 11 & & 500 & 10 & 44.6 & 21.2 & 65.8 & 67.8 & 32.90 \\
\hline 12 & & 600 & 10 & 47.2 & 27.5 & 74.7 & 63.2 & 37.35 \\
\hline 13 & & 600 & 9 & 48.0 & 25.7 & 73.7 & 65.1 & 36.85 \\
\hline 14 & & 600 & 8 & 47.9 & 24.3 & 72.2 & 66.3 & 36.10 \\
\hline 15 & 3 & 100 & 12 & 23.2 & 11.0 & 34.2 & 67.7 & 17.10 \\
\hline 16 & & 200 & 12 & 26.6 & 14.9 & 41.5 & 64.2 & 20.75 \\
\hline 17 & & 400 & 12 & 27.9 & 17.7 & 45.6 & 61.1 & 22.80 \\
\hline 18 & & 500 & 12 & 31.4 & 22.9 & 54.3 & 57.9 & 27.15 \\
\hline 19 & & 600 & 12 & 32.7 & 26.6 & 59.3 & 55.2 & 29.65 \\
\hline 20 & & 600 & 11 & 31.5 & 26.7 & 58.2 & 54.1 & 29.10 \\
\hline 21 & & 600 & 10 & 32.1 & 25.5 & 57.6 & 54.1 & 28.80 \\
\hline
\end{tabular}

[a] solvent $=\mathrm{CH}_{3} \mathrm{CN}, 333 \mathrm{~K}$, oxidant $=$ hydrogen peroxide. [b] Calculated after treatment with $\mathrm{PPh}_{3}$. [c] TON: turn over number $=$ moles of product $/$ mole of catalyst. 
Table 5. Oxidation ${ }^{[a]}$ of cyclohexane by complexes 1,2 and $\mathbf{3}$.

\begin{tabular}{|c|c|c|c|c|c|c|c|c|}
\hline \multirow[b]{2}{*}{ Entry } & \multirow[b]{2}{*}{ Catalysts } & \multirow[b]{2}{*}{$\begin{array}{l}n\left(\mathrm{H}_{2} \mathrm{O}_{2}\right) / \\
n(\text { catalyst })\end{array}$} & \multirow[b]{2}{*}{ Time/h } & \multicolumn{3}{|c|}{ Yield $(\%)^{[b]}$} & \multirow{2}{*}{$\begin{array}{l}\text { Cyclohexanol } \\
\text { Selectivity (\%) }\end{array}$} & \multirow[b]{2}{*}{$\mathrm{TON}^{[\mathrm{c}]}$} \\
\hline & & & & Cyclohexanol & Cyclohexanone & Total & & \\
\hline 1 & 1 & 100 & 10 & 39.5 & 26.6 & 66.1 & 59.7 & 33.05 \\
\hline 2 & & 200 & 10 & 42.8 & 29.7 & 72.5 & 59.1 & 36.25 \\
\hline 3 & & 400 & 10 & 43.8 & 33.1 & 76.9 & 56.9 & 38.45 \\
\hline 4 & & 500 & 10 & 45.8 & 35.7 & 81.5 & 56.2 & 40.75 \\
\hline 5 & & 500 & 9 & 46.8 & 40.1 & 86.9 & 53.8 & 43.45 \\
\hline 6 & & 500 & 8 & 48.0 & 38.2 & 86.2 & 55.7 & 43.10 \\
\hline 7 & 2 & 100 & 10 & 43.5 & 16.0 & 59.5 & 73.1 & 29.75 \\
\hline 8 & & 200 & 10 & 45.7 & 17.9 & 63.6 & 71.9 & 31.80 \\
\hline 9 & & 400 & 10 & 45.7 & 20.8 & 66.5 & 68.7 & 33.25 \\
\hline 10 & & 500 & 10 & 51.3 & 24.3 & 75.6 & 67.9 & 37.80 \\
\hline 11 & & 500 & 9 & 58.1 & 26.7 & 84.8 & 68.5 & 42.40 \\
\hline 12 & & 500 & 8 & 58.1 & 26.0 & 84.1 & 69.1 & 42.05 \\
\hline 13 & 3 & 100 & 11 & 23.5 & 13.0 & 36.5 & 64.3 & 18.25 \\
\hline 14 & & 200 & 11 & 31.0 & 17.4 & 48.4 & 64.1 & 24.20 \\
\hline 15 & & 400 & 11 & 37.1 & 22.4 & 59.5 & 62.3 & 29.75 \\
\hline 16 & & 500 & 11 & 38.4 & 25.2 & 63.6 & 60.3 & 31.80 \\
\hline 17 & & 500 & 11 & 44.2 & 29.7 & 73.9 & 59.8 & 36.95 \\
\hline 18 & & 500 & 10 & 41.8 & 31.2 & 73.0 & 57.2 & 36.50 \\
\hline
\end{tabular}

[a] solvent $=\mathrm{CH}_{3} \mathrm{CN}, 333 \mathrm{~K}$, oxidant $=$ hydrogen peroxide. [b] Calculated after treatment with $\mathrm{PPh}_{3}$. [c] TON: turn over number $=$ moles of product $/$ mole of catalyst.

Table 6. Minimum inhibitory concentrations (MIC) for the complexes 1-4 $\left(\mu \mathrm{g} \mathrm{ml}^{-1}\right)$.

\begin{tabular}{|c|c|c|c|c|c|c|c|}
\hline \multirow[b]{2}{*}{ Compound } & \multicolumn{5}{|c|}{ Antibacterial activity } & \multicolumn{2}{|c|}{ Antifungal activity } \\
\hline & S. aureus & B. subtilis & E. coli & P. aeruginosa & K. pneumonia & C. albicans & S. cerevisiae \\
\hline 1 & $>50$ & $>50$ & 25 & 50 & $>50$ & $>50$ & $>50$ \\
\hline 2 & 25 & 12.5 & 50 & 6.25 & 50 & $>50$ & $>50$ \\
\hline 3 & $>50$ & 6.25 & $>50$ & 12.5 & $>50$ & 50 & 6.25 \\
\hline 4 & $>50$ & $>50$ & $>50$ & $>50$ & $>50$ & 25 & 12.5 \\
\hline
\end{tabular}

metal-promoted homolytic decomposition, would lead to O-centred organoradicals. These are the oxyl ( $\left.\mathrm{RO}^{*}\right)$ and the peroxyl (ROO) radicals formed upon $\mathrm{O}-\mathrm{O}$ and $\mathrm{O}-\mathrm{H}$ bond cleavage, respectively, from which the final oxidation products could be obtained. Alcohols $(\mathrm{ROH})$ could then be formed by $\mathrm{H}$-abstraction from $\mathrm{RH}$ by RO or upon decomposition of ROO to both alcohol and aldehyde/ketone. ${ }^{34 a, 36 b, d, 37}$ The presence of $\mathrm{ROOH}$ at the end of the reaction is shown by the increase of the amount of alcohol with a corresponding decrease in that of the aldehyde/ketone, upon treatment of the final reaction solution with an excess of $\mathrm{PPh}_{3}$ prior to the GC analysis, according to the method reported by Shulpin. Reduction of ROOH by $\mathrm{PPh}_{3}$ gives alcohol, thus eliminating the decomposition of $\mathrm{ROOH}$ to both alcohol and aldehyde/ketone in the gas chromatograph.

\subsection{Antimicrobial activity}

The amide ligand and its copper(II) complexes (14) were evaluated for in vitro antibacterial activity against Gram-positive Bacillus subtilis, Staphylococcus aureus, Gram-negative Escherichia coli, Pseudomonas aeruginosa, Klebsiella pneumonia and in vitro antifungal activity against Saccharomyces cerevisiae, Candida albicans. Muller Hinton, Potato dextrose broth and agar were employed for bacterial and fungal growth, respectively. Minimum Inhibitory Concentrations (MIC) were determined by disc diffusion $\operatorname{method}^{27}$ and are presented in table 6 . Neither the free ligand nor the copper(II) salts inhibited growth of the tested organisms at concentrations below $500 \mu \mathrm{g} \mathrm{mL}^{-1}$.

Table 6 indicates that metal complex $\mathbf{2}$ and $\mathbf{3}$ showed good antibacterial activity against Bacillus subtilis and 
Pseudomonas aeruginosa. Complex $\mathbf{2}$ showed no activity against fungi whereas complex $\mathbf{4}$ exhibited no antibacterial activity. It can be noted that complex $\mathbf{3}$ inhibited growth of both bacterial and fungal strains. On the other hand, complex $\mathbf{1}$ behaves neither as good antimicrobial agent nor as antifungal agent. Complexes $\mathbf{3}$ and $\mathbf{4}$ showed good antifungal activity against Saccharomyces cerevisiae. All the metal complexes exhibited better activity than ligand and copper(II) salts such as $\mathrm{Cu}\left(\mathrm{ClO}_{4}\right)_{2} \cdot 6 \mathrm{H}_{2} \mathrm{O}$ and $\mathrm{CuCl}_{2} \cdot 6 \mathrm{H}_{2} \mathrm{O}$.

\section{Conclusions}

Four water soluble copper(II) complexes with pyridine 2-carboxamide (HL), namely $\left[\mathrm{Cu}(\mathrm{HL})_{2}\left(\mathrm{H}_{2} \mathrm{O}\right)_{2}\right] \mathrm{Cl}_{2}(\mathbf{1})$,

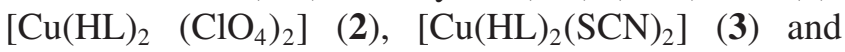
$\left[\mathrm{CuL}_{2}\right] \cdot 8 \mathrm{H}_{2} \mathrm{O}(4)$ were synthesized and fully characterized by spectroscopic methods. Structures of the complexes were determined by single-crystal X-ray analysis. Complexes 1-3 have been effectively used as catalysts for the oxidation of toluene, ethyl benzene and cyclohexane in the presence of hydrogen peroxide as the oxidant under mild conditions to give the corresponding alcohols, aldehydes or ketones. Among the three complexes, 1 emerged as the most effective catalyst. Antimicrobial properties of all four synthesized copper(II) complexes were investigated thoroughly. Complexes $\mathbf{2}$ and $\mathbf{3}$ showed good antibacterial activity against Bacillus subtilis (MTCC 441) and Pseudomonas aeruginosa (MTCC 2453). Complexes 3 and 4 revealed promising results as antifungal agents, especially against Saccharomyces cerevisiae (MTCC 170).

\section{Supplementary Information}

ORTEP representations and $\mathrm{H}$-bonding (figures S1S3), crystal packing views of 1-3 (figure S4-S7), cyclic voltammograms of complexes 1-4 (figure S8), potentiometric titration curve for the complex 1 (figure S9), tables S1-S7, scheme S1, synthesis and characterization of the ligand HL, and crystal structure descriptions for complexes $\mathbf{1}$ and $\mathbf{3}$ are available at www.ias.ac.in/ chemsci. CCDC-1011671(1), 1011672(2), 1011673(3) and $1011674(4)$ contain the supplementary crystallographic data for this paper. These data can be obtained free of charge from The Cambridge Crystallographic Data Centre via www.ccdc.cam.ac.uk/data_request/cif.

\section{Acknowledgements}

We gratefully acknowledge Dr. Papu Biswas for his help and suggestions during the course of this work and in the preparation of the manuscript. Authors also acknowledge DST-India for the Fast Track Project (No.SR/FT/CS-022/2009). S.S. is indebted to CSIR, India for his JRF [08/003(0083)/2011-EMR-1]. Thanks are due to the Department of Science and Technology, Government of India for establishing the National X-ray diffractometer facility at the Department of Inorganic Chemistry, Indian Association for the Cultivation of Science.

\section{References}

1. Backvall J-E 2004 In Modern Oxidation Methods (VCH-Wiley: Weinheim)

2. (a) Sheldon R A, Arends I W C E, Ten Brink G J and Dijksman A 2002 Acc. Chem. Res. 35 774; (b) Piera J and Bäckvall J -E 2008 Angew. Chem. Int. Ed. 473506

3. Guidoni L, Spiegel K, Zumstein M and Rothlisberger U 2004 Angew. Chem. 433286

4. (a) Itoh S 2003 In Comprehensive Coordination Chemistry 2nd ed. Vol. 8 J A McCleverty, T J Meyer, L Que and W B Tolman (Eds.) (Elsevier: Dordrecht) p. 369; (b) Lee D H ibid p. 437; (c) Frafflsto da Silva J J R and Williams R J P 2001 In The Biological Chemistry of the Elements (Oxford University Press: Oxford)

5. Punniyamurthy T and Rout L 2008 Coord. Chem. Rev. 252134

6. Mijangos E, Reedijk J and Gasque L 2008 Dalton Trans. 1857

7. (a) Kirillov A M, Kopylovich M N, Kirillova M V, Haukka M, da Silva M F C G and Pombeiro A J L 2005 Angew. Chem. Int. Ed. 44 4345; (b) Silva T F S, Mishra G S, da Silva M F C G, Riccardo W, Martins L M D R S and Pombeiro A J L 2009 Dalton Trans. 9207; (c) Kirillova M V, Kirillov A M, da Silva M F C G and Pombeiro A J L 2008 Eur. J. Inorg. Chem. 3423; (d) Nicola C Di, Karabach Y Y, Kirillov A M, Monari M, Pandolfo L, Pettinari C and Pombeiro A J L 2007 Inorg. Chem. 46 221; (e) Kopylovich M N, Nunes A C C, Mahmudov K T, Haukka M, Mac Leod T C O, Martins L M D R S, Kuznetsov M L and Pombeiro A J L 2011 Dalton Trans. 40 2822; (f) Figiel P J, Kirillov A M, da Silva M F C G, Lasri J and Pombeiro A J L 2010 Dalton Trans. 39 9879; (g) Kopylovich M N, Mahmudov K T, da Silva M F C G, Figiel P J, Karabach Y Y, Kuznetsov M L, Luzyanin K V and Pombeiro A J L 2011 Inorg. Chem. 50 918; (h) Roy P and Manassero M 2010 Dalton Trans. 391539

8. (a) Velusamy $\mathrm{S}$ and Punniyamurthy $\mathrm{T} 2003$ Tetrahedron Lett. 44 8955; (b) Würtele C, Sander O, Lutz V, Waitz T, Tuczek F and Schindler S 2009 J. Am. Chem. Soc. 131 7544; (c) Lucas H R, Li L, Narducci Sarjeant A A, Vance M A, Solomon E I and Karlin K D 2009 J. Am. Chem. Soc. 131 3230; (d) Roy P, Dhara K, Manassero $\mathrm{M}$ and Banerjee P 2008 Eur. J. Inorg. Chem. 4404

9. (a) Mohammed H M, Zahed K J and Dadkhoda G 2004 J. Chem. Res. 5 364; (b) Velusamy S, Kumar A V, Saini R and Punniyamurthy T 2005 Tetrahedron Lett. 463819

10. Andrus M B and Poehlein B W 2000 Tetrahedron Lett. 411013

11. Borkow G and Gabbay J 2009 Curr. Chem. Biol. 3272 
12. (a) Hodgson D J 1975 Prog. Inorg. Chem. 19 173; (b) Melnik M 1982 Coord. Chem. Rev. 42 259; (c) Kato M and Muto Y 1988 Coord. Chem. Rev. 92 45; (d) Weder J E, Dillon C T, Hambley T W, Kennedy B J, Lay P A, Biffin J R, Regtop H L and Davies N M 2002 Coord. Chem. Rev. 23295

13. (a) Sorenson J R J, 1989 Prog. Med. Chem. 269 437; (b) Sorenson J R J 1984 Chem. Br. 201110

14. (a) Dwyer F P, Reid I K, Shulman A, Laycock G M and Dixson S 1969 Aust. J. Exp. Biol. Med. Sci. 47 203; (b) Zoroddu M Antonietta, Zanetti S, Pogni R and Basosi R 1996 J. Inorg. Biochem. 63 29; (c) Ng N S, Leverett P, Hibbs D E, Yang Q, Bulanadi J C, Wua M J and Wright J R Aldrich 2013 Dalton Trans. 42 3196; (d) Psomas G, Tarushi A, Efthimiadou E K, Sanakis Y, Raptopoulou C P and Katsaros N 2006 J. Inorg. Biochem. 100 1764; (f) Wallis S C, Gahan L R, Charles B G, Hambley T W and Duckworth P A 1996 J. Inorg. Biochem. 62 1; (g) Creaven B S, Devereux M, Karcz D, Kellett A, McCann M, Noble A and Walsh M 2009 J. Inorg. Biochem. 103 1196; (h) Creaven B S, Devereux M, Foltyn A, McClean S, Rosair G, Thangella V R and Walsh M 2010 Polyhedron 29 813; (i) Creaven B S, Duff B, Egan D A, Kavanagh K, Rosair G, Thangella V R and Walsh M 2010 Inorg. Chim. Acta 363 4048; (j) Creaven B S, Egan D A, Kavanagh K, McCann M, Mahon M, Noble A, Thati B and Walsh M 2005 Polyhedron 24 949; (k) Creaven B S, Egan D A, Karcz D, Kavanagh K and McCann M 2007 J. Inorg. Biochem. 1011108

15. Belda $\mathrm{O}$ and Moberg C 2005 Coord. Chem. Rev. 249727

16. Sigel H and Martin R B 1982 Chem. Rev. 82385

17. (a) Rajput A and Mukherjee R 2013 Coord. Chem. Rev. 257 350; (b) Singh A K, Jacob W, Boudalis A K, Tuchagues J P and Mukherjee R 2008 Eur. J. Inorg. Chem. 2820; (c) Khavasi H R, Sasan K, Pirouzmand M and Ebrahimi S N 2009 Inorg. Chem. 485593

18. (a) Mascharak P K 2002 Coord. Chem. Rev. 225 201; (b) Harrop T C and Mascharak P K 2004 Acc. Chem. Res. 37 253; (c) Kovacs J A 2004 Chem. Rev. 104825

19. (a) Sharma A K, Biswas S, Barman S K and Mukherjee R 2010 Inorg. Chim. Acta 363 2720; (b) Jacob W, Mishra H, Pandey S, Lloret F and Mukherjee R 2009 New J. Chem. 33 893; (c) Singh A K and Mukherjee R 2008 Dalton Trans. 260; (e) Singh A K and Mukherjee R 2005 Inorg. Chem. 44 5813; (f) Singh A K and Mukherjee R 2005 Dalton Trans. 2886; (g) Patra A K, Ray M and Mukherjee R 2000 Inorg. Chem. 39 652; (h) Patra A K, Ray M and Mukherjee R 1999 J. Chem. Soc. Dalton Trans. 2461

20. (a) Srinivas P, Likhar P R, Maheswaran H, Sridhar B, Ravikumar K and LakshmiKantam M 2009 Chem.-Eur. J. 15 1578; (b) Mishra A, Ali A, Upreti S and Gupta R 2008 Inorg. Chem. 47 154; (c) Qi J Y, Ma H X, Li X J, Zhou Z Y, Choi M C K, Chan A S C and Yang Q Y 2003 Chem. Commun. 1294

21. (a) Beckmann U, Bill E, Weyhermüller T and Wieghardt K 2003 Inorg. Chem. 42 1045; (b) Dutta S K, Beckmann U, Bill E, Weyhermüller T and Wieghardt K 2000 Inorg. Chem. 393355

22. (a) Harrop T C, Olmstead M M and Mascharak P K 2005 Inorg. Chem. 44 9527; (b) Marlin D S, Olmstead M M and Mascharak P K 2002 Eur. J. Inorg. Chem. 859
23. (a) Dasgupta M, Tadesse H, Blake A J and Bhattacharya S 2008 J. Organomet. Chem. 693 3281; (b) Hazra S, Naskar S, Mishra D, Gorelsky S I, Figgie H M, Sheldrick W S and Chattopadhyay S K 2007 Dalton Trans. 4143

24. (a) Sieroń L and Bukowska-Strżyzewska M 1997 Acta Cryst. C 53 296; (b) Sieroń L and BukowskaStrżyzewska M 1998 Acta Cryst. C 54 322; (c) Sieroń L and Bukowska-Strżyzewska M 1999 Acta Cryst. 55 491; (d) Du Q Y, Xin L -Y, Li Y P and Cao D S 2006 Chin. J. Struct. Chem. 25 295; (e) Đaković M, Vila-Viçosa D, Bandeira N A G, Calhorda M J, Kozlevčar B, Jagličić Z and Popović Z 2013 Cryst. Eng. Comm. 15 8074; (f) Đaković M, Vila-Viçosa D, Calhorda M J and Popović Z 2011 Cryst. Eng. Comm. 13 5863; (g) Brown D H, MacSween D R, Mercer M and Sharp D W A $1971 J$. Chem. Soc. A 1574

25. Perrin D D, Armarego W L and Perrin D R 1980 In Purification of Laboratory Chemicals 2nd ed (Oxford, U.K.: Pergamon)

26. Schaefer F C and Krapcho A P 1962 J. Org. Chem. 27 1255

27. (a) Bauer A W, Perry D M and Kirby W M M 1959 A. M. A. Arch. Intern. Med. 104 208; (b) Bauer A W, Kirby W M M, Sherris J C and Turck M 1966 Am. J. Clin. Pathol. 36 493; (c) Winn Jr W et al. 2006 In Konemann's color atlas and diagnostic text of microbiology $6^{\text {th }}$ ed. (Lippencott, Williams \& Wilkins Publishers, Philadelphia) pp. 945-1021; (d) Jorgensen J H, Turnidge J D 2007 In Susceptibility test methods: dilution and disk diffusion methods p.1152; (e) Murray P R, Baron E J, Jorgensen J H, Landry M L and Pfaller M A (ed.) In Manual of clinical microbiology $9^{\text {th }}$ ed. (Washington, D.C.: ASM Press)

28. SAINT, 2002 version 6.02, SADABS, version 2.03. (Bruker AXS, Inc.: Madison, WI)

29. SHELXTL, 2002 version 6.10, (Bruker AXS, Inc.: Madison, WI)

30. Sheldrick G M, SHELXL-97, (University of Göttingen: Göttingen, Germany)

31. (a) Ghosh S K, Ribas J and Bharadwaj P K 2004 Cryst. Eng. Comm. 6 250; (b) Carballo R, Covelo B, Fernández-Hermida N, García-Martínez E, Lago A B, Vázquez M and Vázquez-López E M 2006 Cryst. Growth Des. 6 629; (c) Ghosh S K and Bharadwaj P K 2004 Inorg. Chem. 43 6887; (d) Mascal M, Infantes L and Chisholm J 2006 Angew. Chem. Int. Ed. 45 32; (e) Mukhopadhyay U and Bernal I 2006 Cryst. Growth Des. 6 363; (f) Yu K Y, Kirillov Alexander M, Fátima M, da Silva C Guedes, Maximilian K N and Armando P 2006 Cryst. Growth Des. 62200

32. (a) Wei M, Willett R D and Hipps K W 1996 Inorg. Chem. 35 5300; (b) Stange A F, Waldhör E, Moscherosch M and Kaim W Z 1995 Naturforsch. 50b 115; (c) Kivelson D and Neiman R 2004 J. Chem. Phys. 35149

33. (a) Nawata Y, Iwasaki H and Saito Y 1967 Bull. Chem. Soc. Jpn. 40 515; (b) Chang S C, Park D Y and Li N C 1968 Inorg. Chem. 7 2144; (c) Fan D, Yang C T, Ranford J D and Vittal J J 2003 Dalton Trans. 4749; (d) Hill D T, Burns K, Titus D D, Girard G R, Reiff W M and Mascavage L M 2003 Inorg. Chim. Acta 346 1; (e) Sanchez G, Vives J, Lopez G, Serrano J L, Garcia L and 
Perez J 2005 Eur. J. Inorg. Chem. 2360; (f) Wang P, Miller J E, Henling L M, Stern C L, Frank N L, Eckermann A L and Meade T J 2007 Inorg. Chem. 46 9853; (g) Albinati A, Lianza F, Muller B and Pregosin P S 1993 Inorg. Chim. Acta 208 119; (h) Brunner H, Nuber B and Prommesberger M 1996 J. Organomet. Chem. 523179

34. (a) Shuĺpin G B 2002 J. Mol. Catal. A-Chem. 189 39; (b) Shilov A E and Shuĺpin G B 2000 In Activation and Catalytic Reactions of Saturated Hydrocarbons in the Presence of Metal Complexes (Dordrecht, The Netherlands: Kluwer Academic Publishers)

35. (a) Kirillov A M, Kopylovich M N, Kirillova M V, Haukka M, Guedes da Silva M F C and Pombeiro A J L 2005 Angew. Chem., Int. Ed. 44 4345; (b) Kirillov A M, Kopylovich M N, Kirillova M V, Karabach E Yu, Haukka M, da Silva M F C G and Pombeiro A J L 2006 Adv. Synth. Catal. 348 159; (c) Shuĺpin G B, Mishra G S, Shuĺpina L S, Strelkova T V and Pombeiro A J L 2007 Catal. Commun. 8 1516; (d) Nicola C D, Karabach Y Yu, Kirillov A M, Monari M, Pandolfo L,
Pettinari C and Pombeiro A J L 2007 Inorg. Chem. 46 221; (e) Nicola C D, Garau F, Karabach Y Y, Martins L M D R S, Monari M, Pandolfo L, Pettinari C and Pombeiro A J L 2009 Eur. J. Inorg. Chem. 666; (f) Silva T F S, Mishra G S, da Silva M F G, Wanke R, Martins L M D R S and Pombeiro A J L 2009 Dalton Trans. 9207

36. (a) Shuĺpin G B, Gradinaru J and Kozlov Y N 2003 Org. Biomol. Chem. 1 3611; (b) Süss-Fink G, Gonzalez L and Shuĺpin G B 2001 Appl. Catal. A 217 111; (c) Shuĺpin G B, Kozlov Y N, Nizova G V, Süss-Fink G, Stanislas S, Kitaygorodskiy A and Kulikova V S $2001 \mathrm{~J}$. Chem. Soc. Perkin Trans. 2 1351; (d) Shuĺpin G B, Stoeckli-Evans H, Mandelli D, Kozlov Y N, Vallina A T, Woitiski C B, Jimenez R S and Carvalho W A 2004 J. Mol. Catal. A: Chem. 219 255; (e) Reis P M, Silva J A L, Palavra A F, Fráusto da Silva J J R, Kitamura T, Fujiwara Y and Pombeiro A J L 2003 Angew. Chem., Int. Ed. 42 821; (f) Roy P and Manassero M 2010 Dalton Trans. 391539

37. Silva T F S, Alegria E C B, Martins L R and Pombeiro A J L 2008 Adv. Synth. Catal. 350706 